\title{
Spring fuelling by arctic Dunlins Calidris a. alpina in the southern Baltic and the potential role of a changing climate
}

\author{
Fettupplagring under våren hos kärrsnäppa Calidris a. alpina $i$ södra Östersjön \\ och möjliga följder av en klimatändring
}

\author{
JOHAN STEDT \& ÅKE LINDSTRÖM
}

\begin{abstract}
In spring, Dunlins Calidris a. alpina put on substantial fuel stores in the North Sea region before a long flight to breed in northwest Russia. There are hitherto no welldescribed fuelling sites in the Baltic region. In May and early June in 2004-2010 we trapped more than 1000 Dunlins at Ottenby, south-east Sweden. Most birds carried substantial fuel loads already when first trapped (much more than in autumn) and, more importantly, 37 within-season re-traps increased in mass at an average rate of $1.2 \mathrm{~g} / \mathrm{d}$. This corresponds to a fuelling rate of about $2.6 \%$ of lean body mass per day, among the highest recorded for this species. Stopover times were short; only $3.5 \%$ of the birds were re-trapped and they stayed on average only 2.2 days. Since the late 1970 s, increas-
\end{abstract}

\section{Abstract}

Received 6 September 2012, Accepted 29 October 2012, Editor: S. Svensson

\section{Introduction}

Large numbers of arctic-breeding waders spend the non-breeding season at food-rich coastal sites along the East Atlantic flyway, such as many of the Calidris species, Turnstone Arenaria interpres, Grey Plover Pluvialis squatarola and Bar-tailed Godwit Limosa lapponica (Alerstam 1990, Piersma 1997). In late spring they depart from foodrich staging sites in north-west Europe towards breeding grounds on the tundra. Most of the birds seem to reach their breeding grounds in one or two long final flights, covering distances of up to 5000 $\mathrm{km}$. They achieve this by putting on fuel stores of 50-70\% above their lean body mass (e.g. Piersma \& Jukema 1990, Gudmundsson et al. 1991). For coastal-bound waders migrating towards the Russian Arctic, the last well-described fuelling sites are found in the UK and in the Wadden Sea (Pienkowski et al. 1979, Johnson 1985, Prokosch 1988, Goede et al. 1990, Gudmundsson et al. 1991, Rösner 1997). There are to our knowledge no regular major fuelling sites for these typically coastal arctic waders in spring in the Baltic region (Blomqvist et al. 2007).

Many waders departing from the North Sea ing numbers of Dunlins stop over at successively earlier dates. This coincides with an increase in spring temperature of $1.1-2.0^{\circ} \mathrm{C}$ in $1977-2010$. Possibly, a warming climate has facilitated and selected for a gradual shift of the final fuelling sites closer towards the breeding grounds.

Johan Stedt, School of Natural Sciences, Linnaeus University, S-391 82 Kalmar, Sweden, and Ottenby Bird Observatory, PO Box 1500, S-380 65 Degerhamn, Sweden. E-mail:johan.stedt@lnu.se.

Ake Lindström, Department of Biology, Biodiversity unit, Lund University, Ecology Building, S-223 62 Lund, Sweden region towards the Russian Arctic crosses southern Sweden. These waders are in Sweden mainly recorded in active migratory flight, or resting on the ground in small numbers (Blomqvist \& Lindström 1992, 1995, Gudmundsson 1994, Blomqvist et al. 2007). Big flocks are occasionally seen on the ground, but mainly in connection with adverse weather conditions, such as strong headwinds and heavy rain (Breife 1976, Waldenström 1987). The general pattern therefore seems to be that arctic waders stop in southern Baltic only briefly during spring migration and that no fuelling takes place. There are two known potential exceptions. Large numbers of Dunlins Calidris alpina were observed several springs in the 1990s near Hiddensee, in the SW corner of the Baltic Sea, where they were found foraging on wind-exposed sandflats throughout May and into early June (Dierschke \& Helbig 1999). Further, Bar-tailed Godwits are regularly seen staging and feeding intensively in spring in the Öresund region in southwesternmost Sweden (Green 1999). However, in these two studies there were no data presented on foraging or fuelling rates.

An important reason for making a final long flight 
up to the breeding grounds is probably the lack of good feeding sites in the Baltic region. For birds that want to maximize speed of migration, which may be the case for many wader species (Alerstam \& Lindström 1990), the usage of a given site is dependent on the fuel deposition rate achieved at that site and the distance to other potential stopover sites (Gudmundsson et al. 1991). Flying long distances require large fuel stores, and carrying large fuel stores therefore adds an extra energy cost to migration. However, if fuel can be added at a comparatively high rate, the fastest migration can be achieved by putting on large fuel loads at a distant stopover site with subsequent over-flying of sites where fuelling is possible, but at comparatively low rates (Gudmundsson et al. 1991). Although the fuelling rates at several major sites in north-west Europe are well described, no comparable data to our knowledge exist on spring fuelling rates in the Baltic region, should such fuelling at all occur.

In Sweden, most arctic waders are observed at spring dates in late May and early June coinciding with the known major exodus from key staging sites and subsequent arrival to the breeding grounds (Blomqvist \& Lindström 1992, 1995, Green et al. 2003, Blomqvist et al. 2007). This further suggests that there is a general strategy of a last long direct flight into the breeding grounds. Nevertheless, each year smaller numbers of arctic waders such as Red Knot Calidris canutus, Little Stint C. minuta, Sanderling C. alba, Curlew Sandpiper C. ferruginea, Bar-tailed Godwit and Grey Plover are observed well into Sweden already one or two weeks before the peak passage, $500-1000 \mathrm{~km}$ away from the nearest staging sites in the Wadden Sea (Blomqvist \& Lindström 1992, 1995, Green et al. 2003, Blomqvist et al. 2007). These birds are obviously much too early for arrival at their arctic breeding grounds. This led Green et al. (2003) to suggest that, for Bar-tailed Godwits, there may be yet undiscovered small scale stopover sites in Sweden and elsewhere in the Baltic region. They also suggested that such early migration may have become more common in recent warmer years. This, of course, may hold also for other arctic waders.

The recent climate warming in northern Europe has had strong effects on the temporal pattern of bird migration, leading to earlier arrival to the breeding grounds in many migrants (Lehikoinen et al. 2004, Stervander et al. 2005, Jonzén et al. 2006). The reason for an earlier arrival may be improved conditions along the migration route, allowing a faster migration (cf. Ahola et al. 2004). Also the spatial pattern of bird migration may change over time (Sutherland 1998, Eichhorn et al. 2009). Lindström \& Agrell (1999) reviewed the potential effects of climate warming may have on the migration of Arctic-breeding waders and predicted that new stopover sites may form closer to the breeding grounds. Although Bauer et al. (2008) found that arctic-breeding geese stayed longer at traditional staging sites between winter and breeding quarters as spring came earlier, there has as yet been no reports of new sites being used due to climate change (but see Green et al. 2003).

In this paper we describe spring fuelling by arctic Dunlins Calidris a. alpina at Ottenby, Sweden. Ottenby is situated at the southern tip of the island Öland in the Baltic Sea, about $600 \mathrm{~km}$ northeast of the nearest well-known staging site in the Wadden Sea (Rösner 1997, Figure 1). We compare the rate and amount of fuel deposited to that recorded at other sites in spring and autumn, and also reflect upon the importance of recent climate change for our findings.

\section{Methods}

Study site and data collection

Autumn trapping of waders at Ottenby Bird Observatory $\left(56^{\circ} 12^{\prime} \mathrm{N}, 16^{\circ} 24^{\prime} \mathrm{E}\right)$ in south-eastern Sweden has been carried out yearly since 1946 (Edelstam 1972, Waldenström \& Lindström 2001). In contrast, almost no ringing of spring migrating arctic waders has been carried out. However, in the springs of 2004-2010, arctic waders on spring migration were caught on the shorelines near the bird observatory, mainly to study the prevalence of avian influenza virus (Wallensten et al. 2007). It is noteworthy that there is almost no tide around the shores of Ottenby, and accordingly, no tidal mud flats to feed on. At Ottenby the birds forage on the banks of decaying seaweed that irregularly occur around the shoreline. The main food is probably dipteran larvae (visual observations), but no systematic studies have been carried out.

The main aim of starting spring trapping was to catch sub-arctic and arctic breeding waders. Therefore, trapping was not initiated until well into May, when these birds (in some years) start to appear in catch-worthy numbers and when the local breeders are already nesting. Trapping efforts ended in early June when the shores were empty of arctic waders. In total 50-100 walk-in funnel traps of "Ottenby-model" (Bub 1991) were activated on the shorelines, mainly on rottening sea-weeds. The traps were checked hourly during the light part of the day. Traps were only activated 


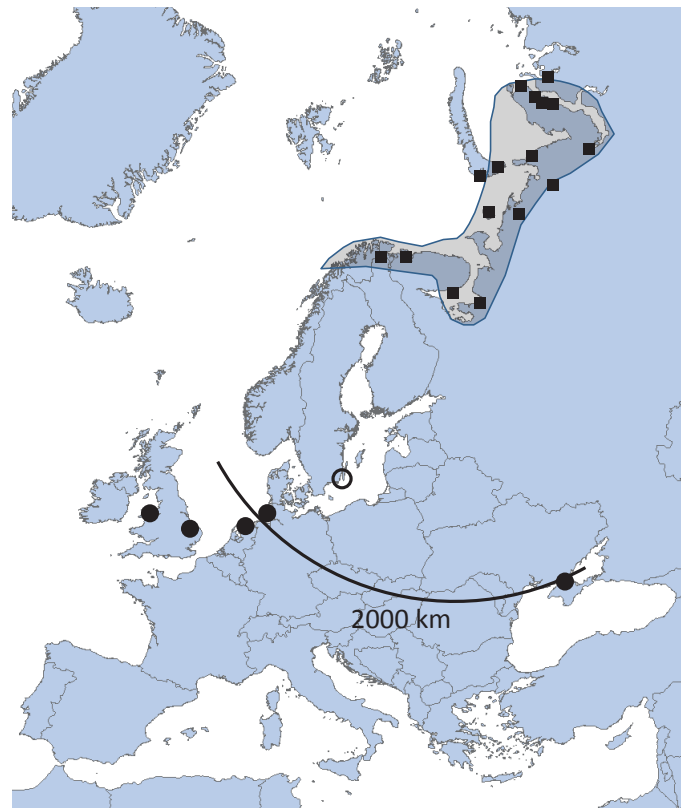

Figure 1. The shaded area shows the presumed breeding areas of birds passing Ottenby (circle) in late May and early June (cf. Engelmoer \& Roselaar 1998). Black squares within this area show sites where birds ringed or controlled at Ottenby have been recorded. Dunlins of the alpina subspecies also breed in the alpine regions of northern Norway and Sweden, but there are no recoveries connecting Ottenby to this area. The arc denotes the $2000 \mathrm{~km}$ distance from the southwest corner of the depicted breeding grounds (the White Sea), which is the approximate distance within which the nearest well-described fuelling sites are situated. The distance to Ottenby is about $1400 \mathrm{~km}$. Well-known spring fuelling sites (black dots) are from left to right: The Dee Estuary and the Wash in the UK, the Wadden Sea in The Netherlands and Germany, respectively, and Shivash in Ukraine. From these sites there are departure body masses from late May of birds supposedly bound for breeding grounds in N Scandinavia or NW Russia (for details, see Table 1). The map is a Polar projection.

Det skuggade området visar det förmodade häckningsområdet för de kärrsnäppor som flyttar förbi Ottenby under slutet av maj och början av juni. Svarta fyrkanter visar platser där kärrsnäppor ringmärkta eller kontrollerade vid Ottenby blivit anträffade. Kärrsnäppor av rasen alpina häckar också $i$ svenska och norska fjällkedjan, men det finns inga återfynd med Ottenbyanknytning därifrån. Halvcirkeln visar distansen 2000 km från häckningsområdet. Det är det ungefärliga avstånd där de närmaste kända fettupplagringslokalerna finns. Avståndet till Ottenby från häckningsområdet är ca $1400 \mathrm{~km}$. Välkända fettupplagringslokaler visas med svarta punkter. Från dessa lokaler finns vikter innan flyttning från senare delen av maj för fåglar som häckar i norra Skandinavien eller Ryssland (Tabell 1). Kartan visas i polarprojektion. when more than c. 20 Dunlins were staging in the trapping area.

All birds were ringed and processed in the laboratory of the bird observatory, which is within 200 $\mathrm{m}$ of the catching area. Second calendar-year $(2 \mathrm{y})$ birds were separated from adult birds $(3 \mathrm{y}+)$ on their retained juvenile inner median wing coverts (Prater et al. 1977). A few birds of the subspecies Calidris alpina schinzii were also trapped, identified on plumage characters (less distinct black belly-patch) and shorter bill, but they were excluded from the analyses. The following biometrics were collected: wing length, using the maximum chord method (Svensson 1992); total head-length, from bill-tip to back of skull (Green 1980); body mass measured to the nearest $0.1 \mathrm{~g}$ by using an electronic balance, and the visible fat load as seen in the tracheal pit, on a scale from $0-9$ (the scale of Pettersson \& Hasselquist 1985, extended with classes 7-9). As in passerines, fat scores can be used to estimate fuel stores in waders (Lindström 1998). Over the seven years, more than $80 \%$ of the birds were ringed by the same six ringers and calibrations between these and additional ringers were carried out regularly.

The lean body mass (LBM) of a bird is a useful measure when comparing fuel deposition patterns between species and studies (Alerstam \& Lindström 1990). Since we did not dissect any birds, we need to rely on other sources for an estimate of LBM. An early study at Ottenby estimated LBM to be around $41 \mathrm{~g}$ (Mascher \& Marcström 1976), but was made in late autumn on juveniles only (Table 1). Instead we chose to use $46 \mathrm{~g}$ as LBM in spring, being the average of birds with no or only small fat stores in the Dutch Wadden Sea (Goede et al. 1990).

In a few instances we wanted to compare Dunlins caught in spring and autumn respectively. We then used the data on all adult Dunlins $(2 \mathrm{y}$ and $3 \mathrm{y}+$, see below) trapped in the autumns of 2004 and 2005. The standardised wader trapping in autumn starts 1 July and continues to mid or late September, depending on the numbers of staging waders in the area. For further information on fuel deposition in autumn migrating Dunlins at Ottenby, see Mascher \& Marcström (1976) and Holmgren et al. (1993).

We also looked through the Ottenby diaries from 1 May to 11 June for the years 1977-2010 and extracted all observations of staging Dunlins. Species presence is always noted in the diaries, but it is up to the staff to decide which birds in spring that should be counted and taken notes of. Since the Dunlin is a rather common bird that also breed in the Ottenby area, some of the variation in numbers 
recorded may be due to different ambition levels of the staff, at least when it comes to reporting smaller flocks. However, it should be noted that staging waders are easy to observe, not least large flocks, since they occur in open terrain within a few hundred meters of the observatory, and the staff is continuously present in the area. Thus, in years when only a few observations of small Dunlin flocks have been reported, it is highly unlikely that large flocks have been present. No doubt, a large majority of flocks of hundred birds or more actually present have been noted in the diary.

\section{Study population}

So far there are no recoveries from the breeding grounds of birds caught during spring migration at Ottenby. From recoveries of birds ringed at Ottenby in autumn we know that most of them breed on the tundra from north-east Finland in the west to the Yamal and Gydanskij peninsulas in the east (Figure 1). The most easterly recovery is from a bird ringed as juvenile at Ottenby 10 August 1987 and controlled 1 July 1989 at appr. $70^{\circ} 00^{\prime} \mathrm{N}, 77^{\circ} 00^{\prime} \mathrm{E}$ on the Gydanskij Peninsula, $3200 \mathrm{~km}$ eastnortheast of Ottenby. The winter recoveries come from all countries along the shores of western Europe, mainly from France and the United Kingdom, but also from the Mediterranean area and West Africa. Building on these recoveries we assume that the bulk of Dunlins passing Ottenby in autumn are of the alpina subspecies (Engelmoer \& Roselaar 1998).

\section{Weather data}

Monthly average temperature $\left({ }^{\circ} \mathrm{C}\right)$ and precipitation (mm) at Ottenby in March, April and May in 1977-2010 were retrieved from http://luftweb. smhi.se/.

\section{Statistics}

All statistics, mainly General Linear Models, were carried out in SPSS 17.0. Non-significant interaction terms were removed before calculating the final models. All measurements were not taken on every bird, therefore n-values can vary somewhat between analyses. In 2006, 2008 and 2009, the birds were trapped within a very short time period each year. Therefore, data from these three years were not included in analyses involving how morphometrics varied with dates within and between years.

\section{Results}

Phenology and numbers of staging birds

The number of birds reported from staging on the shores around the bird observatory between 1 May to 11 June in 1977-2010 varied dramatically between days (0 to 2000) and years (from 0 to 5600, Figure 2). We divided the period into four sub-periods of 8-9 years: 1977-1984 (period I), 1985-1992 (II) and 1993-2001 (III), and 2002-2010 (IV).

There was a general increase in the number of birds reported per spring. The yearly average of

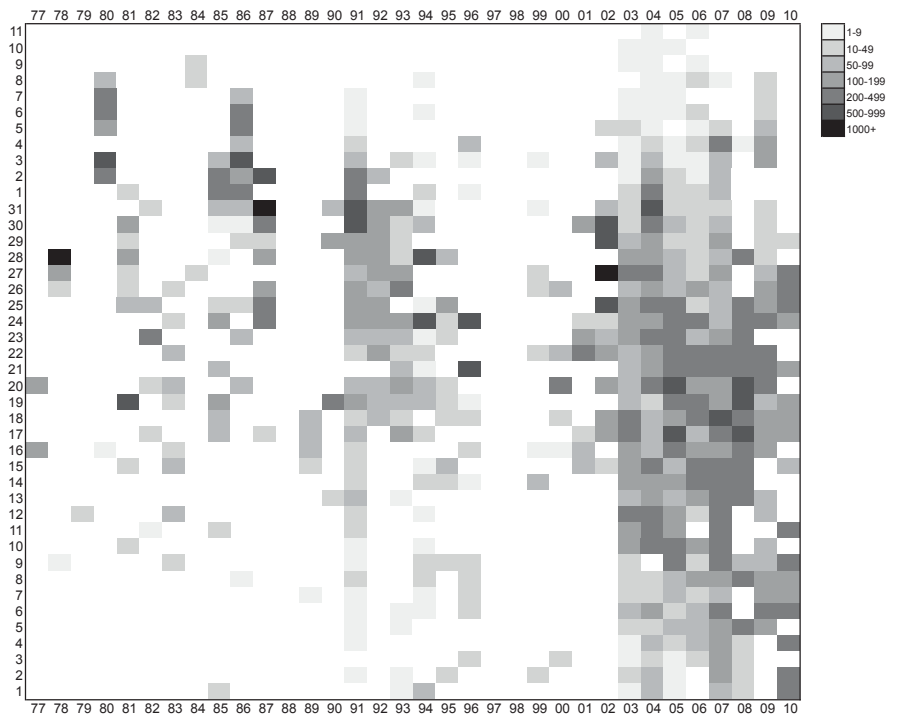

Figure 2. Observations of Dunlins staging at the shorelines around Ottenby Bird Observatory, 1 May - 11 June (vertical axis) in 1977-2010 (horizontal axis). The different shades of grey denote different maximum numbers of staging birds per day. The gradual shift of dark colours towards the lower right in the graph indicates that the birds have been appearing earlier and earlier at Ottenby over the study period.

Observationer av kärrsnäppor rastande runt Ottenby fågelstation 1 maj - 11 juni (vertikal axel) 1977-2010 (horisontell axel). De olika nyanserna av grå visar olika dagliga maxantal av rastande fåglar. Den gradvisa förändringen till mörkare grå mot nedre högra hörnet $i$ grafen indikerar att fåglar dyker upp allt tidigare på Ottenby under studieperioden. 
birds recorded was about 775, 1550, 675 and 4108 for the four periods respectively. The yearly average number of days with more than 100 birds reported was $1.25,3.75,1.44$ and 12.2 for the four periods. Although the trapping efforts the last seven years also resulted in more careful recording of the birds present, we feel confident that there has been a true increase in the number of birds observed (Figure 2).

From a phenology perspective, Dunlins have occurred on average earlier and earlier at Ottenby. In years with at least three records of staging Dunlins, the day with the highest number occurred between 19 May and 3 June in period I (median 28 May), 16-30 May in period II (30 May), 15-31 May in period III (24 May) and 17-26 May in period IV (21 May). Not only did the peak of staging occur progressively earlier, also the start of migration seems to have changed. In 1977-2002, the first day with more than 100 birds on the shores never occurred before 16 May. In 2003-2010, the first day with more than 100 birds recorded were $10,6,9,8$, 2, 5, 5 and 1 May respectively.

The highest numbers of birds on the shores were normally found in unstable weather conditions, but large flocks can also appear in sunny weather. Foraging on the seaweed is mainly taking place in connection to rainy or cloudy weather. When the weather has been sunny for a longer period, the birds are normally found roosting on rocks. For example, much fewer birds were trapped in 2006 and 2009 compared to the other years included in the study, although the numbers seen were about the same. The cages we use cannot be used out on the rocks and are also inefficient if the birds do not forage.

\section{Numbers and age distribution of birds ringed}

The spring data consists of 1053 first captures of Dunlins, including 15 already ringed birds. The latter were either ringed at Ottenby in a previous spring $(n=1)$ or autumn $(n=4)$ or ringed at other locations than Ottenby $(\mathrm{n}=10)$. The birds were trapped during the following periods: 11 May-3 June $2004(\mathrm{n}=173), 10-26$ May $2005(\mathrm{n}=496)$, 18-23 May $2006(\mathrm{n}=30), 9$ May-5 June 2007 $(\mathrm{n}=284), 17$ May-19 May $2008(\mathrm{n}=3), 21$ May-5 June $2009(n=50)$ and 2 May-28 May $2010(n=17)$. As far as age is concerned, 391 birds were $2 \mathrm{y}$ and 601 birds were $3 y+(61$ birds were not aged). In the autumns of 2004 and 2005, in total 9982 adult birds $(2 \mathrm{y}$ and $3 \mathrm{y}+)$ were trapped.

Although average trapping dates varied signifi- cantly between spring seasons, there was no significant effect of age on trapping dates (two-way ANOVA, effect of year: $\mathrm{F}_{6.984}=269.1, \mathrm{p}<0.001$, effect of age: $F_{1.984}=3.0, p=0.082$ ). Further, there were significant average differences in morphometrics between $3 y+$ and $2 y$ birds both in wing length and body mass (t-test, wing: 120.8 vs. $120.3 \mathrm{~mm}$, $\mathrm{p}=0.014$ ), body mass: 63.6 vs. $61.6 \mathrm{~g}, \mathrm{p}<0.001$ ). For total head there was no significant average difference (57.2 vs. $56.9 \mathrm{~mm}, \mathrm{p}=0.19)$. Median fat score was significantly higher in $3+$ birds (median 7) than in $2 y$ birds (median 6, U-test $\mathrm{p}<0.001$, $\mathrm{n}=599$ and 389 , respectively). Thus, there was no significant difference in timing of spring migration between the age groups, but some significant (but small) differences in their morphometrics.

\section{Fuel deposition and morphometrics at the population level}

There are two main ways of determining fuel deposition rates in a population like the one we have studied (Lindström 2003). One way is to look at mass changes in retrapped individuals. Another way is to assume that the birds trapped belong to a closed population, that is, the birds arrive at the same time, stay together over the whole trapping period, and then depart synchronously. If so, it is reasonable to assume that the average individual fuel deposition rate equals the average change in body mass of the population.

Among the birds trapped in spring, both body mass and fat scores generally increased with date, but at different rates in different years (ANCOVA, body mass: interaction term date* year: $\mathrm{F}_{3.538}=5.3$, $\mathrm{p}=0.001$; fat score: interaction term, date*year: $\left.\mathrm{F}_{3.539}=4.8, \mathrm{p}=0.003\right)$. Calculating a linear regression for each year separately $(2004,2005,2007$ and 2010) we found that body mass increased on average with $0.42,0.95,0.50$ and $0.11 \mathrm{~g} / \mathrm{d}$, with a four-year average of $0.5 \mathrm{~g} / \mathrm{d}$. The average fat score increased with $0.12,0.18,0.07$ and 0.09 units/d, with a four-year average of 0.12 units/d. Over a three week period, this roughly equals a $10.5 \mathrm{~g}$ increase in body mass and a 2.5 unit increase in fat score (Figure 3 and 4). There was a strong positive correlation between body mass and fat score $\left(r_{973}=0.61, p<0.001\right)$, showing that much of the variation in body mass could be explained by the amount of visible fat.

Both wing length and total head was strongly influenced by trapping date and there were significant differences between years (ANCOVA, date: $\mathrm{F}_{1.905}=12.3, \mathrm{p}<0.001$; year: $\mathrm{F}_{3.905}=7.4, \mathrm{p}<0.001$; 


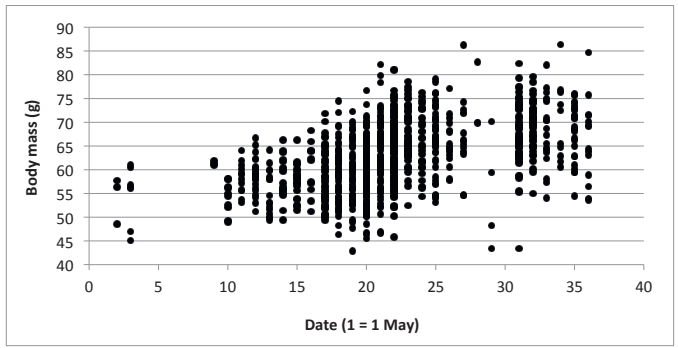

Figure 3. Body mass of Dunlins trapped at Ottenby, southeastern Sweden, in spring 2004-2010. Each dot is one individual.

Vikter på kärrsnäppor fångade vid Ottenby under vårarna 2004-2010. Varje punkt är en individ.

age: $\left.\mathrm{F}_{1.905}=0.82, \mathrm{p}=0.36\right)$. The pattern for total head was more complicated, since there was a marginally significant three-way interaction (ANCOVA, date*year*age: $\mathrm{F}_{3.895}=2.6, \mathrm{p}=0.049$ ). However, if ignoring this interaction term, the pattern is very similar to that of wing length (ANCOVA, date: $\mathrm{F}_{1.905}=24.1, \mathrm{p}<0.001 ;$ year: $\mathrm{F}_{3.905}=10.9, \mathrm{p}<0.001$; age: $\left.\mathrm{F}_{1.905}=0.2, \mathrm{p}=0.66\right)$. Using linear regression for age classes combined and each year separately (2004, 2005, 2007 and 2010) we found that wing length increased on average with $0.13(\mathrm{p}=0.006)$, $0.06(p=0.20), 0.09(p=0.021)$ and $0.01(p=0.84)$ $\mathrm{mm} / \mathrm{d}$, and total head increased with $0.15(\mathrm{p}<0.001)$, $0.14(\mathrm{p}=0.001), 0.12(\mathrm{p}=0.001)$ and $0.00(\mathrm{p}=0.96)$ $\mathrm{mm} / \mathrm{d}$. Over a three week period, this roughly equals a $0.2-2.7 \mathrm{~mm}$ increase in wing length and a 0-3.2 $\mathrm{mm}$ increase in total head length.

Clearly, the Dunlins at Ottenby in spring did not form a closed population. Instead there was probably a continuous turnover of individuals with gradually longer wings and longer bills the further the season progressed. Accordingly, estimating a fuel deposition rate for individual birds from changes in the population average may in this case give an unrepresentative value.

\section{Individual fuel deposition rates}

The other main way of estimating fuel deposition rate is to look at re-trapped birds. In total 37 birds $(3.5 \%)$ were re-trapped the same spring season one or more days after first capture (Figure 5). For these birds the minimum length of stay (number of days between first and last capture) was on average 2.2 days (range 1-9 days). The average change in mass between first and last capture was $2.5 \mathrm{~g}$ (range -3.1-13.8 $\mathrm{g}$ ) and the average fuel deposition rate was $1.2 \mathrm{~g} / \mathrm{d}$ (range $-2.9-6.2 \mathrm{~g} / \mathrm{d}$ ). In total 25 of the 37 birds increased in mass during their

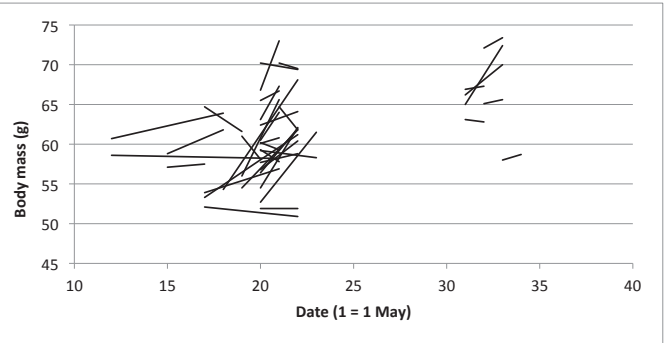

Figure 5. Body mass changes of Dunlins recaptured one or more days after first capture, at Ottenby, south-eastern Sweden, in spring 2004-2010.

Viktförändringar hos kärrsnäppor återfångade en eller flera dagar efter första fångst på Ottenby under vårarna 20042010.

stay ( $68 \%$ of all retraps). Among these birds, average mass increase was $4.3 \mathrm{~g}$ at a rate of $2.1 \mathrm{~g} / \mathrm{d}$.

Assuming a lean body mass of $46 \mathrm{~g}$, the average fuel deposition rate of all birds were $2.6 \%$ of $\mathrm{LBM} / \mathrm{d}$, and $4.6 \%$ of $\mathrm{LBM} / \mathrm{d}$ for the sub-group where all increased in mass. The three fastest individual fuel deposition rates were $6.2 \mathrm{~g} / \mathrm{d}$ (from 66.8 $\mathrm{g}$ to $73.0 \mathrm{~g}$ in 1 day), $4.8 \mathrm{~g} / \mathrm{d}$ (from $56 \mathrm{~g}$ to $65.6 \mathrm{~g}$ in 2 days), and $4.2 \mathrm{~g} / \mathrm{d}$ (from $63.1 \mathrm{~g}$ to $67.3 \mathrm{~g}$ in 1 day). This corresponds to fuel deposition rates of $13.7,10.7$ and $9.3 \%$ of $\mathrm{LBM} / \mathrm{d}$, respectively.

\section{Body mass and fuel stores}

The overall average body mass for all spring Dunlins was $62.7 \mathrm{~g}(\mathrm{n}=1047, \mathrm{SD}=7.1$, range $=42.9-86.4$ g) and median fat score was $6(n=1049$, range $1-9)$. This is equivalent to fuel stores of on average 36.3 $\%$ of LBM. However, the body mass and fuel

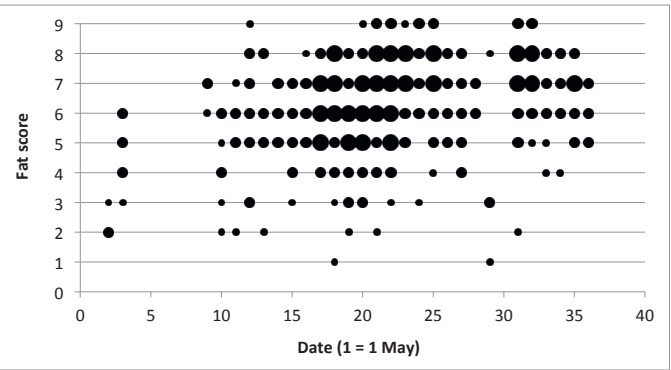

Figure 4. Fat score of Dunlins Calidris a. alpina trapped at Ottenby, south-eastern Sweden, in spring 2004-2010. Small dots denote 1 bird, medium sized dots $2-10$ individuals, and large dots more than 10 birds.

Mängden synligt fett hos kärrsnäppor ringmärkta vid Ottenby under vårarna 2004-2010, klassat på en skala 0-9. Små punkter visar 1 individ, mellanstora punkter 5-10 individer, och stora punkter $>10$ individer. 
stores of Dunlins increased throughout the spring study period (Figure 3 and 4). The 20 first caught birds trapped 2-10 May had an average mass of $54.9 \mathrm{~g}(\mathrm{SD}=5.1$, range $=45.1-61.9)$ and the median fat score was 4 . This is equivalent to fuel stores of $19.4 \%$ of LBM. In the seasonally 20 latest birds, 4-5 June, where most birds must have been close to a final departure towards the breeding grounds, average mass was $68.8 \mathrm{~g}(\mathrm{SD}=8.4$, range $=53.6-$ 84.7 ) and median fat score 6 . This is equivalent to fuel stores of on average $49.6 \%$ of LBM.

In autumn, the overall average body mass of adult birds was $48.2 \mathrm{~g}(\mathrm{n}=9672, \mathrm{SD}=4.2$, range $=$ 35.7-69.4) and median fat score was $4(n=10392$, $\mathrm{SD}=1.1$, range $1-8)$. These values are significantly lower than the spring values (mass, t-test: $\mathrm{t}=96.3$, $\mathrm{p}<0.001$; fat score: U-test, $\mathrm{z}=42.4, \mathrm{p}<0.001$ ). The overall fuel load in autumn is equivalent to on average only $4.8 \%$ of LBM. However, it seems as if LBM may generally be lower in autumn (Table 1). Assuming a more reasonable LBM of $42 \mathrm{~g}$ gives an average fuel load of about $15 \%$ above the LBM.

\section{Dunlin populations in spring and autumn}

For all Dunlins measured during spring migration the wing length was $120.6 \mathrm{~mm}(\mathrm{n}=1051, \mathrm{SD}=2.9$, range $=112-129)$ and bill-head $57.0 \mathrm{~mm}(\mathrm{n}=1050$, $\mathrm{SD}=2.7$, range $=50-64$ ). During autumn migration 2004-2005, the mean wing length for all $2 y$ and $3 \mathrm{y}+$ birds was $120.1 \mathrm{~mm}(\mathrm{n}=9921, \mathrm{SD}=3.0$, range $=111-126)$ and bill-head $56.9 \mathrm{~mm}(\mathrm{n}=9920$, $\mathrm{SD}=2.7$, range $=51-64$ ). In addition, twenty Dunlins ringed during spring migration were recaptured at Ottenby during subsequent autumn migrations, and three Dunlins ringed during autumn migration were recaptured in a subsequent spring. Together this suggests that the same population(s) are passing Ottenby in spring and autumn.

\section{Weather}

As estimated by linear regression, the monthly average temperature $\left({ }^{\circ} \mathrm{C}\right)$ in spring generally increased over the study period 1977-2010, although significantly so only for April (March, $+0.037^{\circ} \mathrm{C}$ / year, $\mathrm{p}=0.25$; April, $+0.062^{\circ} \mathrm{C} /$ year, $\mathrm{p}<0.001$; May, $+0.034^{\circ} \mathrm{C} /$ year, $\mathrm{p}=0.12$ ). Numerically, this is equal to an overall increase of $1.1-2.0{ }^{\circ} \mathrm{C}$ in 33 years. Changes in precipitation were less consistent. It decreased significantly over time in March $(-0.70$ $\mathrm{mm} /$ year, $\mathrm{p}=0.01)$, showed no trend in April $(-0.21$ $\mathrm{mm} /$ year, $\mathrm{p}=0.48)$, and had a tendency to increase in May $(+0.79 \mathrm{~mm} /$ year, $\mathrm{p}=0.052)$.

\section{Discussion}

There are three particularly noteworthy findings to discuss regarding the Dunlins stopping over in spring at Ottenby. First, a majority of the Dunlins re-trapped within the same spring season increased in mass. As far as we know, this is the first time that more regular fuel deposition of Dunlins (or any wader species) in spring has been documented in the Baltic region. Second, there seems to be a continuous turnover of birds in spring, as judged from the short stopover duration of re-trapped birds and the gradual increase in size. This is in contrast to the general pattern found for spring migrating arctic-breeding waders in north-west Europe, where most birds seem to fuel and depart synchronously, for a final long flight to the breeding grounds (Pienkowski et al. 1979, Johnson 1985, Prokosch 1988, Goede et al. 1990, Gudmundsson et al. 1991, Rösner 1997). Third, the occurrence of staging birds at Ottenby has changed over the study period. The birds have arrived gradually earlier in spring, and in increasing numbers.

\section{Rate and amount of fuel deposition}

For the re-trapped birds that increased in mass we estimated the fuel deposition rate to be on average $2.6 \%$ of $\mathrm{LBM} / \mathrm{d}$, and the maximum rate found for an individual was $13.7 \%$ of LBM/d. Although the very short time period over which the individual mass gain was measured calls for careful interpretation, the values are higher than all other values we have found reported for Dunlins in north-west Europe in spring (Table 1). Further, they are close to the maximum reported for any waders of this size from around the world (Lindström 2003). They are also similar to the values reported from Ottenby in autumn (Holmgren et al. 1993). The shores around Ottenby apparently provided excellent foraging and fuelling conditions for spring migrating Dunlins.

How can such high rates be achieved? We have no systematic measures of food abundance along the Ottenby shores. However, the banks of decaying seaweed clearly provide an excellent food source in wetter weather, with the substrate teeming with invertebrate life. This is clearly in contrast to dry weather conditions, when a hard crust is created on the seaweed surface, making invertebrate food largely unavailable (personal observations). An additional advantage at Ottenby is that once good conditions prevail, the birds can probably feed also at night, an important prerequisite for fast fuelling (Lindström 2003). In tidal areas 


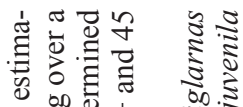
200 गे

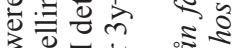

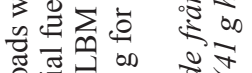

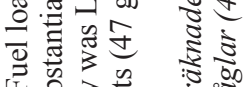

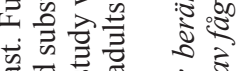
क्ष क्ष

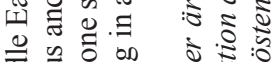

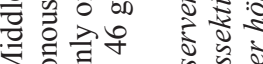

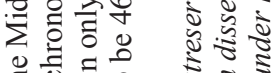

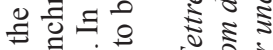

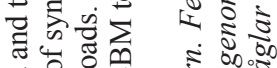

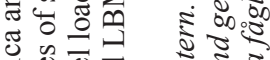

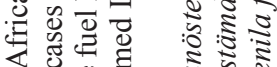

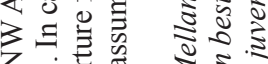

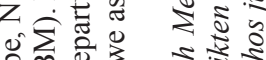

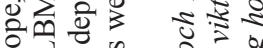

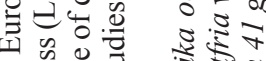

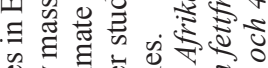

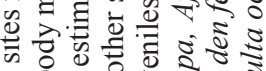

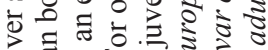

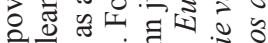

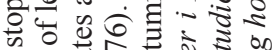

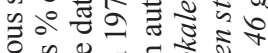
ชำ

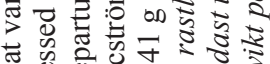

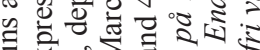

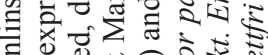

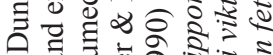

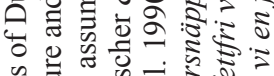
पु

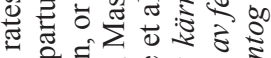

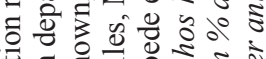

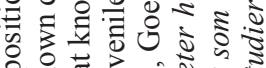

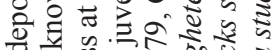

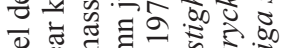

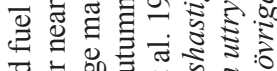

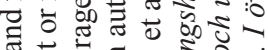

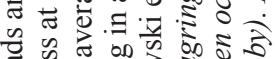
वै की

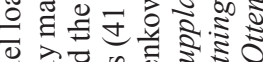

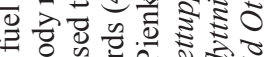
0830 过

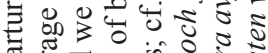

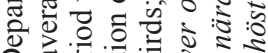

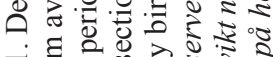

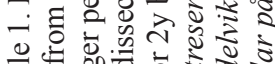
녕

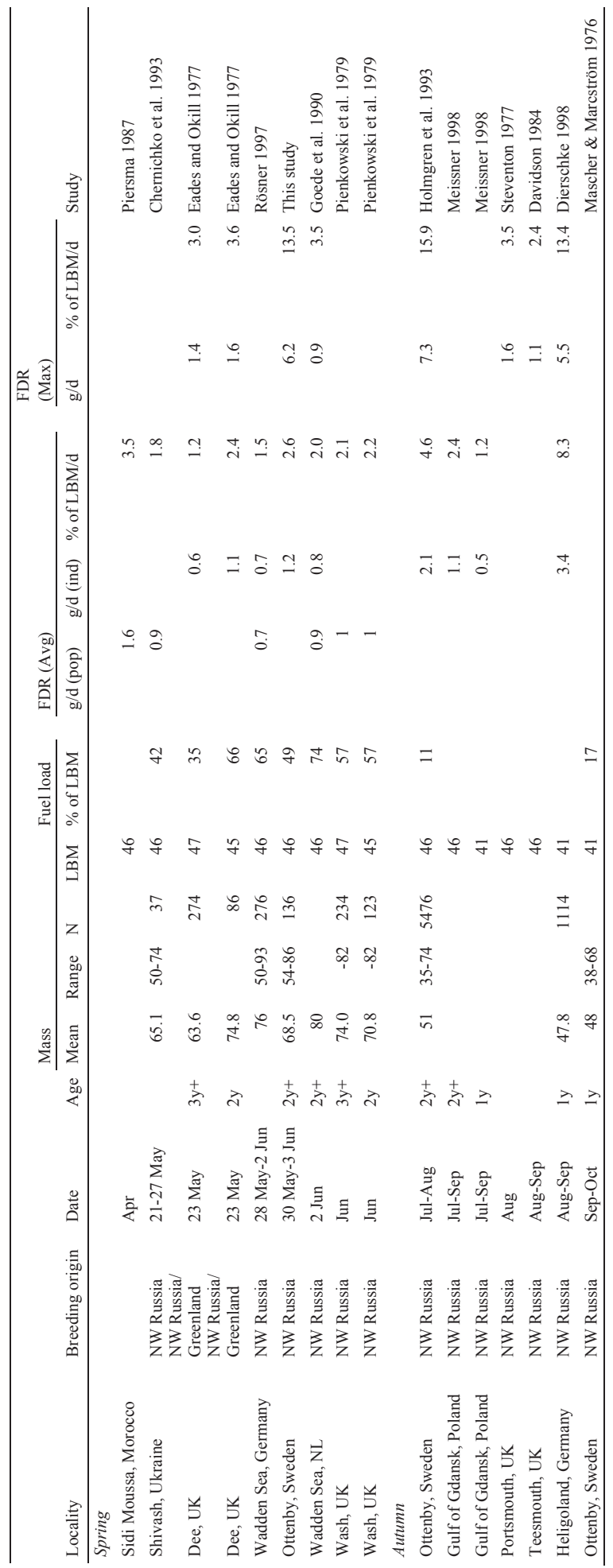


much potential feeding time is lost when roosting, and long distances to suitable high-tide roosts can restrain foraging possibilities even further (Dias et al. 2006).

Although the numbers staging in spring are comparably small, it seems as if the spring birds belong to the same population(s) as the birds passing Ottenby in autumn. Average size was very similar in spring and autumn, and several birds were trapped in both seasons. This makes a comparison between seasons even more valid. Not only fuelling rates but also the length of stay of re-trapped birds was similar between seasons. Among the birds staying for $20 \mathrm{~h}$ or more, Holmgren et al. (1993) found an average length of stay of about 2 days in autumn to be compared with the 2.4 days in spring. Obviously Dunlins do not use Ottenby for longer periods of stay either in spring or autumn. Little is known about individual travelling schedules among Dunlins, but short stopover periods may actually be characteristic for this species. Warnock et al. (2004) followed individual Dunlins with radio-transmitters during spring migration along the Pacific coast of North America and found mean length of stay at various sites along the route to vary between 1 and 3.8 days between individuals.

What did differ strongly between seasons at Ottenby was the size of the fuel stores, which were much larger in spring. The overall mass of $62.8 \mathrm{~g}$, and a peak average of $68.8 \mathrm{~g}$ in early June, are substantially higher than the $51 \mathrm{~g}$ found in the autumns of 1985-1988 (Holmgren et al. 1993) and the average mass of $47.6 \mathrm{~g}$ for adults in the autumns of 2004-2005 reported here. This indicates that the birds stopping at Ottenby in spring are bound for much longer non-stop flights than in autumn, although fuel loads at departure can also be higher than needed for covering a certain distance, due to optimality considerations (Alerstam \& Lindström 1990) or the need to carry fuel stores upon arrival at the breeding grounds (Tulp et al. 2009). Stopover duration at Ottenby in spring is short. Therefore, despite the high short-term fuelling rates, most of the fuel stores the birds have when leaving Ottenby are probably deposited at other stopover sites, possibly in the North Sea region where body masses of 64-80 g at departure have been reported (Table 1).

Our finding that some Dunlins in spring put on fuel far into the Baltic region does not alter the existing view that the bulk of Dunlins in northwest Europe depart rather synchronously in late Mayearly June from stopover sites mainly in the North Sea region (Eades \& Okill 1977, Pienkowski et al. 1979, Goede et al. 1990, Rösner 1997). But clearly, some birds have another strategy (see also Dierschke \& Helbig 1999).

\section{A non-synchronous passage}

In addition to the short stopover periods, the gradual increase in wing length and total bill-head show that the birds visiting Ottenby do not belong to a closed and synchronously staging population. In Dunlins of the alpina subspecies, females on average have $3 \mathrm{~mm}$ longer wings and $2-3 \mathrm{~mm}$ longer bills than males (Engelmoer \& Roselaar 1998). The most likely explanation for the gradual increase in size with time is that the proportion of males is high at the beginning of the season and gradually changes in favour of the larger females. Another possibility is that populations of differently sized individuals are passing at different times. This seems less likely, however, since there seems to be no general size differences among Dunlins in northern Fennoscandia and northwest Russia (Engelmoer \& Roselaar 1998).

\section{Moving positions ahead in a climate warming scenario?}

The seemingly continuous turnover of Dunlins at Ottenby in spring indicates that a proportion of the population starts to move towards the breeding grounds well before the majority. The same pattern seems to prevail in Sweden also in other tundrabreeding waders (Blomqvist \& Lindström 1992, 1995, Green et al. 2003, Blomqvist et al. 2007). What does this mean in terms of Dunlin migration strategies? Is this simply an over-seen alternative migration strategy or do we see the development of a new migration strategy? Whether Dunlins have managed to put on fuel at Ottenby also before 2003 we do not know, but successful fuelling may well be a relatively new phenomenon. From the counts at Ottenby it seems as if more and more Dunlins stopover and that the birds occur progressively earlier in spring. But where do the birds visiting Ottenby relatively early in spring go following their short stops? Are there other stopover sites further along the route to Russia or do the Dunlins move around more locally in south Sweden? Or do they even move back to the North Sea area for continued fuelling?

Much attention has recently been given to changes in migration timing of birds due to climate change. Many birds migrate north progressively earlier as a response to warmer springs (e.g. Stervander et al. 2005, Jonzén et al. 2006). Indeed, 
springs have become gradually warmer also at Ottenby the last decades. The change in precipitation is less consistent and also more difficult to interpret. Given the importance in autumn of wet beaches, the tendency for more and more rain in May could possibly facilitate foraging.

Nevertheless, the overall change in spring weather may have improved fuelling conditions at Ottenby. This trend is likely to continue. In a recent report (HELCOM 2007), the spring temperature in the Baltic Sea basin was forecasted to become 3-7 ${ }^{\circ} \mathrm{C}$ warmer at year 2100 , and the growing season will be prolonged by $1-3$ months. This will include an earlier start of plankton growth in spring, which in turn will affect the whole food web (HELCOM 2007), and most likely benefit fuelling in Dunlins.

Lindström \& Agrell (1999) reviewed the potential effects of climate warming may have on the migration of Arctic-breeding waders. One prediction was that new stopover sites may form, closer to the breeding grounds. It seems clear that at least in recent years, there have been excellent fuelling possibilities at Ottenby, that at least some Dunlins have made use of. Gudmundsson et al. (1991) argued that for waders trying to migrate as fast as possible, very long flights are expected if the potential fuelling rates at stopover sites not visited (overflown) are comparatively low. Should the comparatively high fuelling rates we have found at Ottenby continue to be achieved, migrants that want to maximize migration speed should be expected to start using such a stopover site (Gudmundsson et al. 1991). The fact that the wintering grounds of Dunlins have shifted northward in recent decades (Fransson et al. 2008), is another strong indication that Dunlins do adjust important life-history events to climate change.

What possibly speaks against a rapid switch to new stopover sites in the Baltic region such as Ottenby is the potentially low predictability of foraging conditions (cf. Dierschke \& Helbig 1999). As in autumn, in periods of dry and sunny weather, the drying out of the seaweed wreckage most certainly precludes fast fuelling. Fuelling in 2004, 2005 and 2007 was in periods very successful, but in e.g. 2006 conditions seem to have been less favourable. It remains to be seen whether fuelling in the Baltic is a new phenomenon that will develop further along with the forecasted climate warming.

\section{Acknowledgements}

We are most grateful to the dedicated work carried out by volunteers at Ottenby throughout the years. Martin Stervander helped with handling ringing recoveries and Sara Henningsson, Volker Dierschke, Sören Svensson and an anonymous referee gave valuable comments on an earlier version of the manuscript. The standardised ringing at Ottenby is supported by grants from the Swedish Environmental Protection Agency. Important financial support has also been received from the Knut and Alice Wallenberg Foundation, the Marcus and Amalia Wallenberg Foundation, the Carl Trygger Foundation for Scientific Research and Stiftelsen Olle Engkvist Byggmästare (to Ottenby Bird Observatory), and from the Swedish Research Council and The Swedish Research Council for Environment, Agricultural Sciences and Spatial Planning (to Björn Olsen). This is contribution no. 264 from Ottenby Bird Observatory.

\section{References}

Ahola, M., Laaksonen, T., Sippola, K., Eeva, T., Rainio, K. \& Lehikoinen, E. 2004. Variation in climate warming along the migration route uncouples arrival and breeding dates. Global Change Biol. 10: 1610-1617.

Alerstam, T. \& Lindström, Å. 1990. Optimal bird migration: The relative importance of time, energy and safety. Pp. 331-351 in Bird Migration (Gwinner, E. ed.). Springer, Berlin.

Bauer, S., Van Dinther, M., Høgda, K.-A., Klaassen, M., Madsen, J. 2008. The consequences of climate-driven stop-over sites changes on migration schedules and fitness of Arctic geese. J. Anim. Ecol. 77: 654-660.

Blomqvist, S., Green, M. \& Lindström, Å. 2007. The spring migration of Grey Plover Pluvialis squatarola in Sweden. Ornis Svecica 17: 121-136.

Blomqvist, S. \& Lindström, Å. 1992. Routes of spring migrant Siberian and Nearctic Knots Calidris canutus diverge over Sweden. Wader Study Group Bull. 64: 91-94

Blomqvist, S. \& Lindström, A.. 1995. The spring migration of Sanderling Calidris alba, Little Stint C. minuta and Curlew Sandpiper C. ferruginea in Sweden. Ornis Svecica 5: 55-67.

Breife, B. 1976. Arctic waders on Öland 27-30 May 1976. Calidris 5: 75-78. (In Swedish with English summary)

Bub, H. 1991. Bird Trapping and Bird Banding. Cornell Univ. Press, Hong Kong.

Chernichko, I.I., Chernichko, R., Diadicheva, L., van der Have, T.M., Van de Sant, S. 1993. Biometry of waders in the Sivash, Ukraine, spring 1992. WIWO-report 36: 65-85.

Davidson, N. C. 1984. How valid are flight range estimates for waders? Ring. \& Migr. 5: 49-64.

Dias, M.P., Granadeiro, J.P., Lecoq, M., Santos, C.D. \& Palmeirim, J.M. 2006. Distance to high-tide roosts contstrains the use of foraging areas by dunlins: Implications for the management of estuarine wetlands. Biol Conserv. 131: 446-452.

Dierschke, V. 1998. High profit at high risk for juvenile Dunlins Calidris alpina stopping over at Helgoland (German Bight). Ardea 86: 59-69. 
Dierschke, V. \& Helbig, A.J. 1999. Baltic Sea windflats as spring staging site for Dunlins Calidris alpina. Wader Study Group Bull. 90: 42-46.

Eades, R.A. \& Okill, J.D. 1977. Weight changes of Dunlins on the Dee Estuary in May. Bird Study 24: 62-63.

Edelstam, C. 1972. The Visible Migration of Birds at Ottenby, Sweden. Vår fågelvärld, suppl. 7.

Eichhorn, G., Drent, R.H., Stahl, J., Leito, A. \& Alerstam, T. 2009. Skipping the Baltic: the emergence of a dichotomy of alternative spring migration strategies in Russian barnacle geese. J. Anim. Ecol. 78: 63-72.

Engelmoer, M. \& Roselaar, C.S. 1998. Geographical variation in waders. Kluwer, Dordrecht.

Fransson, T., Österblom, H. \& Hall-Karlsson, S. 2008. Svensk ringmärkningsatlas. Vol. 2. Stockholm.

Goede, A.A., Niebor, E. \& Zegers, P.M. 1990. Body mass increase, migration pattern and breeding grounds of Dunlins, Calidris a. alpina, staging in the Dutch Wadden Sea in spring. Ardea 78: 135-144.

Green, G.H. 1980. Total head length. Wader Study Group Bull. 29: 18.

Green, M. 1999. Bar-tailed Godwits Limosa lapponica on south Swedish shores in spring - emergency stopovers or regular occurrence? Ornis Svecica 9: 133-142.

Green, M., Blomqvist, S. \& Lindström, A. 2003. The spring migration of two Bar-tailed Godwit Limosa lapponica populations in Sweden. Ornis Svecica 13: 1-15.

Gudmundsson, G.A. 1994. Spring migration of the Knot Calidris c. canutus over southern Sweden, as recorded by radar. J. Avian Biol. 25: 15-26.

Gudmundsson, G.A., Lindström, Å. \& Alerstam, T. 1991. Optimal fat loads and long-distance flights by migrating Knots Calidris canutus, Sanderlings C. alba and Turnstones Arenaria interpres. Ibis 133: 140-152.

HELCOM. 2007. Climate Change in the Baltic Sea Area HELCOM Thematic Assessment in 2007. Balt. Sea Environ. Proc. No. 111

Holmgren, N., Ellegren, H. \& Pettersson, J. 1993. Stopover length, body mass and fuel deposition rate in autumn migration adult Dunlins calidris alpina: Evaluting the effects of moulting status and age. Ardea 81: 9-19.

Johnson, C. 1985. Patterns of seasonal weight variation in waders on the Wash. Ring. \& Migr. 6: 19-32.

Jonzén, N., Linden, A., Ergon, T., Knudsen, E., Vik, J.O., Rubolini, D., Piacentini, D., Brinch, C., Spina, F., Karlsson, L., Stervander, M., Andersson, A., Waldenström, J., Lehikoinen, A., Edvardsen, E., Solvang, R. \& Stenseth, N.C. 2006. Rapid Advance of Spring Arrival Dates in Long-Distance Migratory Birds. Science 312: 1959-1961.

Lehikoinen, E., Sparks, T.H. \& Zalakevicius, M. 2004. Arrival and departure dates. Pp. 1-31 in Birds and climate change (Møller, A.P., Fiedler, W. and Berthold, P. eds.). Adv. Ecol. Res. 35. Elsevier Science, London.

Lindström, Å. 1998. Mass and morphometrics of Little Stints Calidris minuta on autumn migration along the Arctic coats of Eurasia. Ibis 140: 171-174.

Lindström, Å. 2003. Fuel deposition rates in migrating birds: causes, constraints and consequences. Pp. 307-320 in Avian Migration (Berthold, P., Gwinner, E. \& Sonnenschein, E. eds.). Springer, Berlin.

Lindström, A. \& Agrell, J. 1999. Global change and possible effects on the migration and reproduction of arctic-breeding waders. Ecol. Bull. 47: 145-159.
Mascher, J.W. \& Marcström, V. 1976. Measures, weights, and lipid levels in migrating Dunlins Calidris a. alpina L. at the Ottenby bird observatory, south Sweden. Ornis Scand. 7: 49-59.

Meissner, W. 1998. Fat reserves in Dunlins Calidris alpina during autumn migration through Gulf of Gdańsk. Ornis Svecica 8: 91-102.

Pettersson, J. \& Hasselquist, D. 1985. Fat deposition and migration capacity of Robins Erithacus rubecula and Goldcrests Regulus regulus at Ottenby, Sweden. Ring. \& Migr. 6: 66-76.

Pienkowski, M.W., Lloyd, C.S \& Minton, C.D.T. 1979. Seasonal and migrational weight changes in Dunlins. Bird Study 26: 134-148.

Piersma, T. 1997. Do global patterns of habitat use and migration strategies co-evolve with relative investments in immunocompetence due to spatial variation in parasite pressure? Oikos 80: 623-631.

Piersma, T. \& Jukema, J. 1990. Budgeting the flight of a long-distance migrant: changes in nutrient reserve levels of Bar-tailed Godwits at successive spring staging sites. Ardea 78: 315-337.

Prater, A.J., Marchant, J.H. \& Vuorinen, J. 1977. Guide to the identification and ageing of Holarctic Waders. BTO guide 17, Tring.

Prokosch, P. 1988. The Schleswig-Holstein Wadden Sea as spring staging area for arctic wader populations demonstrated by Grey Plover (Pluvialis squatarola, L. 1758), Knot (Calidris canutus, L. 1758) and Bar-tailed Godwit (Limosa lapponica, L. 1758). Corax 12: 273-442. (In German with English summary)

Rösner, H.U. 1997. Strategies of staging and migration of Dunlin (Calidris alpina) in the Wadden Sea and along the East-Atlantic Flyway. Dissertation, Johann Wolfgang Goethe University, Frankfurt. (In German with English summary)

Stervander, M., Lindström, Å., Jonzen, N. \& Andersson, A. 2005. Timing of spring migration in birds: long-term trends, North Atlantic Oscillation and the significance of different migration routes. J. Avian Biol. 36: 210-221.

Steventon, D. J. 1977. Dunlin in Portsmouth, Langstone and Chichester Harbours. Ring. \& Migr. 1: 141-147.

Sutherland, W. J. 1998. Evidence for flexibility and constraint in migration systems. J. Avian Biol. 29: 441-446.

Svensson, L. 1992. Identification Guide to European Passerines. $4^{\text {th }}$ Ed. Svensson, Stockholm.

Tulp, I., Schekkerman, H., Klaassen, R., Ens, B. \& Visser, G.H. 2009. Body condition of shorebirds upon arrival at their Siberian breeding grounds. Polar Biol. 32: 481-491.

Waldenström, A. 1987. Arctic waders on southern Öland 25 May -1 June 1987. Calidris 16: 199-201. (In Swedish with English summary)

Waldenström, A. 1987. Arctic waders on southern Öland 25 May-1 June 1987 (In Swedish with English summary). Calidris 16: 199-201.

Waldenström, J. \& Lindström Å. 2001. Migration and morphometrics of the Broad-billed Sandpiper Limicola falcinellus at Ottenby, southern Sweden, 1950-2000. Ornis Fenn. 78: 184-192.

Wallensten, A., Munster, V.J., Latorre-Margalef, N., Brytting, M., Elmberg, J., Fouchier, R.A.M., Fransson, T., Haemig, P.D., Karlsson, M., Lundkvist, Å., Osterhaus, A.D.M.E., Stervander, M., Waldenström, J. \& Olsen, 
B. 2007. Surveillance of Influenza A Virus in Migratory Waterfowl in Northern Europe. Emerg. Infect. Dis. 13: 404-411.

Warnock, N., Takekawa, J.Y. \& Bishop, M.A. 2004. Migration and stopover strategies of individual Dunlin along the Pacific coast of North America. Can. J. Zool. 82: 1687-1697.

\section{Svensk sammanfattning}

Stora antal arktiska vadare övervintrar längs Europas näringsrika tidvattenstränder. Flyttningen mot häckområdena på tundran sker under senare delen av våren och genomförs av de flesta arter $\mathrm{i}$ en eller två långa non-stop flyttningar. Under dessa flygningar kan fåglarna avverka distanser på uppemot $5000 \mathrm{~km}$. För att genomföra detta krävs stora bränslereserver (huvudsakligen fett, men också en del protein). Kärrsnäppor Calidris a. alpina och andra arktiska vadare lagrar betydande fettreserver i Nordsjöregionen (motsvarande 50-70 \% över den fettfria vikten) innan den långa flyttningen mot den ryska tundran. I Sverige ses de arktiska vadarna främst under aktivt sträck utan att rasta. Dokumenterade stora ansamlingar av rastande vadare längs Sveriges kuster finns men då främst i samband med ofördelaktigt väder som hårda motvindar och regn. Några kända regelbundna rastplatser för fettupplagring finns inte i Östersjöregionen, med två möjliga undantag: höga antal av kärrsnäppor observerades flera vårar under 1990-talet vid Hiddensee, sydvästra hörnet av Östersjön, samt myrspovar som regelbundet ses födosöka i Öresundsregionen i Sydvästra Sverige. På ingen av dessa platser har det dock genomförts några detaljerade studier av födosök eller fettupplagring.

Vid Ottenby fågelstation på Öland har ringmärkning av höstflyttande vadare bedrivits sedan 1946. Däremot har ingen fångst bedrivits på våren. I samband med studier av så kallad fågelinfluensa, fångades dock vadare under maj och början av juni åren 2004-2010. Fångsten genomförs på ruttnande tångbankar i strandlinjen där fåglarna troligen främst födosöker på fluglarver. Vårfångsten inleddes först under maj månad då lokala vadare redan startat sin häckning eftersom fångsten inriktades på arktiska vadare. Aktiv fångst genomfördes då mer än 20 kärrsnäppor rastade på tångbankarna runt fågelstationen och genomfördes med hjälp av vadarfällor av "Ottenby-modell". Sammanlagt ringmärktes över 1000 kärrsnäppor. Från ringmärkta vadare samlades biometri in i form av vinglängd, huvud-näbb och vikt ( 0,1 g noggrannhet). Dessutom klassades mängden synligt fett på hals och buk enligt en skala från 0 till 9 .
För att uppskatta fettupplagring hos fåglar är även den fettfria vikten hos en art ett användbart mått. Eftersom vi inte dissekerade någon individ har vi använt oss av fettfria vikter från en tidigare genomförd studie från holländska Vadehavet, där man konstaterade att kärrsnäppor utan lagrat fett hade en medelvikt på $46 \mathrm{~g}$.

Vi har jämfört våra vårdata med data från adulta kärrsnäppor ringmärkta på Ottenby under höststräcket 2004-2005. Den standardiserade höstmärkningen av vadare vid Ottenby genomförs från början av juli till slutet av september beroende av vadartillgången runt fågelstationen. Höstmärkningen under de analyserade åren genomfördes till största delen av samma ringmärkare som de under våren ringmärkta individerna.

Ottenby fågelstationen för dagligen dagboksanteckningar där alla anträffade arter inom området noteras. Dessutom görs mer utförligare anteckningar över ovanliga arter och större antal. Vi sammanställde observationerna från 1 maj till 11 juni för åren 1977-2010. Eftersom fågelstationspersonalen väljer vilka observationer som skall antecknas i dagböckerna kan mindre avvikelser mellan åren förekomma, men större ansamlingar av kärrsnäppor, vilket är vårt fokus, bör alltid ha antecknats.

Än så länge finns inga återfynd från häckområden rapporterade från de vårmärkta kärrsnäpporna. Då 20 av de under våren märkta kärrsnäpporna återfunnits på Ottenby nästkommande höst och tre under hösten märkta fåglar återfunnits under påföljande vår drar vi dock slutsatsen att det rör sig om samma population som passerar Ottenby både vår och höst. Från återfynd av höstmärkta kärrsnäppor vet vi att häckområdet sträcker sig från tundran i nordöstligaste Finland till Yamalhalvön (Figur 1). Det östligaste återfyndet från fågelstationen kommer från en ungfågel ringmärkt på Ottenby 10 augusti 1987 som kontrollerades 1 juli 1989 $\left(70^{\circ} 00^{\prime} \mathrm{N}, 77^{\circ} 00^{\prime} \mathrm{E}\right)$ vid Gydanskij Peninsula, 3200 km ostnordost om Ottenby.

Antalet rastande kärrsnäppor vid Ottenby mellan 1 maj-11 juni 1977-2010 varierade kraftigt både mellan dagar (0-2000) och mellan år (0-5600). Den generella trenden är dock att en ökning skett under perioden. Medelantalet per år under fyra perioder (8-9 år per period) var; 1977-1984 (775), 1985-1992 (1550) and 1993-2001 (675) 20022010 (4108). Även antalet dagar med fler än 100 rastande individer visade på en ökning; 1,2, 3,8, 1,4 och 12,2.

Från dagboksanteckningarna drar vi slutsatsen att kärrsnäpporna i medel anlänt tidigare och tidi- 
gare till Ottenby under studieperioden. Datum för dagen med högst antal rastande individer inföll under de fyra perioderna 19 maj-3 juni i period I (median 28 maj), 16-30 maj i period II (30 maj), 15-31 maj i period III (24 maj) och 17-26 maj i period IV (21 maj). Den ökade frekvensen av rastande kärrsnäppor sammanfaller med en generell ökning av vårtemperaturen som stigit $1,1-2,0^{\circ} \mathrm{C}$ mellan 1977 och 2010. Förändringen i mängden regn på våren är mer komplex, men har generellt ökat under maj månad.

De 1053 kärrsnäpporna som ringmärkts under vårfångsten fördelas enligt följande; 11 maj-3 juni $2004(\mathrm{n}=173), 10-26$ maj $2005(\mathrm{n}=496), 18-23$ maj $2006(n=30), 9$ maj-5 juni $2007 \quad(n=284)$, 17 maj-19 maj $2008(n=3), 21$ maj-5 juni 2009 $(n=50)$ and 2 maj-28 maj $2010(n=17)$. Av dessa fåglar var 391 fåglar i sitt andra kalenderår (2y), 601 adulta $(3 y+)$ och 61 med obestämd ålder. Trots att fångstdatum varierade signifikant mellan vårarna fanns det ingen signifikant skillnad i när de olika åldersgrupperna fångades. Under höstarna 2004-2005 ringmärktes totalt 9982 fåglar som var i sitt andra kalenderår eller äldre.

Medelvikten för kärrsnäppor fångade var 62,8 g under våren, att jämföras med 47,6 g på hösten. Detta visar att vårfåglarna bar betydande fettreserver, motsvarande i medeltal $36,3 \%$ av den fettfria vikten. Det fanns en generell ökning i både vikt och fettklassning ju senare under våren fåglarna fångades. Det fanns också ett starkt samband mellan vikt och fettklassning vilket visar att viktökningen kan förklaras av ökning i synligt fett. Vi tittade även på fettupplagring hos enskilda individer genom att använda fåglar som återfångades en eller flera gånger. De fåglar som återfångades ökade $\mathrm{i}$ vikt med $\mathrm{i}$ genomsnitt $1,2 \mathrm{~g} / \mathrm{d}$, vilket betyder en fettlagring motsvarande $2,6 \%$ av den fettfria vikten/dygn. Tiden fåglarna rastar vid Ottenby verkar dock vara kort då endast $3,5 \%$ av fåglarna återfångades och för de återfångade fåglarna var medeltiden mellan första och sista fångst 2,2 dygn. Bara två tredjedelar av de återfångade fåglarna ökade dock i vikt och för dem var hastigheten $2,2 \mathrm{~g} / \mathrm{d}$, vilket motsvarar 4,6 \% av den fettfria vikten/dygn (maximala värdet motsvarade $13,7 \%$ av den fettfria vikten/dygn). Både vinglängd och längden på näbb-huvud ökade med datum hos de rastande fåglarna.

Vi drar tre huvudsakliga slutsatser om kärrsnäppornas vårflyttning förbi Ottenby. För det första har en majoritet av de kärrsnäppor som återfångades under samma vår ökat i vikt. Så vitt vi vet är detta första dokumentationen av regelbunden fettupplagring hos arktiska vadare i Östersjöregionen. För återfångade individer var medel för fettupplagring/ dag $2,6 \%$ av den fettfria vikten, och den maximala ökningen hos en återfångad individ var 13,6 $\%$. Dessa värden är faktiskt högre än några andra vi funnit rapporterade från nordvästra Europa för kärrsnäppa. Ottenbys tångbankar torde därför vara utmärkta för födosök vid rätt förutsättningar.

För det andra verkar det vara stor omsättning av individer under våren. Detta skiljer sig från det generella mönster som ses hos arktiska vadare under vårflyttningen i nordvästra Europa, där de flesta fåglar verkar synkronisera sin fettupplagring och genomföra flytten samtidigt $i$ en lång flygning till häckområdet. Troligen kan detta bero på att hanarna flyttar tidigare för att sedan gradvis övergå till en högre andel honor med längre vinglängd.

För det tredje verkar kärrsnäpporna anlända tidigare till Ottenby nu jämfört med för 30 år sedan och verkar dessutom rasta i högre antal. Är detta en förbisedd alternativ flyttningsstrategi eller ser vi början på en ny sådan? Vårtemperaturen vid Ottenby har under studieperioden ökat, likaså nederbörden under maj. Kanske har detta gynnat kärrsnäppornas födosök i tångbankarna? Om förutsägelser om global uppvärmning uppfylls kan vi då vänta oss att allt fler kärrsnäppor (och andra arktiska vadare) börjar utnyttja Ottenby och andra lokaler i Östersjöregionen för sin fettupplagring på våren? Det faktum att kärrsnäpporna även har förflyttat sitt övervintringsområde norrut under senare år (vilket visas av återfynd av ringmärkta fåglar) är ytterligare en indikation på att global uppvärmning påverkar såväl flyttnings- som övervintringsstrategier hos arten. 